\title{
Penuaan Elektrode CuCr1Zr Spot Welding dengan Pendekatan Numerical
}

\author{
Agus Sifa \\ Politeknik Negeri IndramayuJl.Lohbener Lama No.08, IndramayuPhone: 081215867418 \\ Email: agus.sifa86@gmail.com
}

\begin{abstract}
.
This study is to develop the constitutive equations to describe the mechanical deformation of the surfaces active of electrode. Most of tests are isotherms to characterize the material behavior at each temperature. The results isothermal test are used to identify the parameters of the law by using softwere SiDoLo, it shows the difference affected temperature. We can determine the value of the variable aging is a value between $0-1$, the results identification of material aging through numerical calculations show the final result 0.9 , then we can say that the specimens have been tested aging.
\end{abstract}

Keywords: CuCr1Zr, Mechanical behavior, Aging, Electrode, Spot Welding

\section{PENDAHULUAN}

Beberapa penelitian pada permasalah pelatihan las titik, terutama dalam kasus pengelasan high tensile. Beberapa plat, dilas dengan resistensi, dikembangkan dengan elektroda yang terbuat dari paduan tembaga menggunakan galvanis untuk melawan korosi. Paduan CuCr1Zr (TembagaChrome-Zirkonium) digunakan untuk pembuatan elektroda, mengalami perlakuan panas untuk mengembalikan agar memiliki sifat mekanik dan listrik awal yang optimal. Tetapi akumulasi item pengelasan dapat menyebabkan deformasi dan elektroda erosi yang menyebabkan penuaan yang cepat dan karena penggantian prematur elektroda ini.

Degradasi mekanik melibatkan banyak fenomena digabungkan seperti pelunakan paduan (pelarutan / perpaduan dari endapan pengerasan), kelelahan termomekanik (yang mengakibatkan akumulasi siklus pengelasan) dan serangan kimia oleh liquid zinc. Fenomena ini adalah khusus untuk galvanis atau elektro-galvanis, dalam prakteknya berarti elektroda cepat aus dibandingkan dengan kasus lembar tanpa pelapisan. Hal tersebut untuk memahami dan memodelkan mekanisme degradasi tips pengelasan.

Tujuan dari penelitian ini untuk mengembangkan hukum mekanika untuk menggambarkan deformation behavior permukaan aktif dari elektroda. Jadi, kami melakukan tes Gleeble untuk behavior materil $\mathrm{CuCr} 1 \mathrm{Zr}$ ini. Dan kemudian menguji dengan kontak elektroda dengan disk molibdenum, kami akan memvalidasi hukum perilaku penuaan dengan softwere SiDoLo.

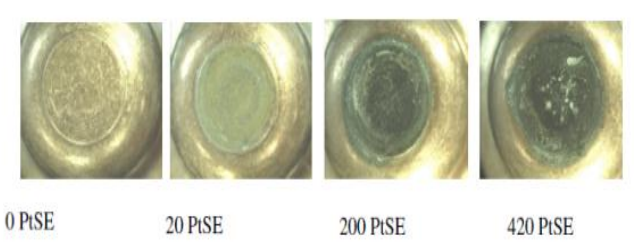

Gambar 1. Permukaan elektroda CuCr1Zr Spot Welding

\section{Gambaran Umum}

\section{CuCr1Zr}

Tembaga memiliki konduktivitas termal tinggi, yang membuatnya menarik terutama untuk Spot Welding.Namun, sifat mekaniknya menurun cepat ketika temperature jenuh.Untuk memperbaiki hal tersebut yang diperlukan menambahkan beberapa paduan.

The $\mathrm{Cu}-\mathrm{Cr}-\mathrm{Zr}$ secara luas telah digunakan dalam bidang pengelasan tetapi juga digunakan oleh industri nuklir untuk sifat fisik material yang baik.

Paduan ini salah satu dari paduan dengan endapan pengerasan.

Pada tabel 1 menunjukkan sifat fisik dari paduan $\mathrm{CuCr} 1 \mathrm{Zr}$ [5].

Tabel 1.Karakteristik fisik paduan $\mathrm{CuCr} 1 \mathrm{Zr}$.

\begin{tabular}{|l|c|}
\hline \multicolumn{1}{|c|}{ Sifat Fisik } & CuCr1Zr \\
\hline Suhu liquid $\left({ }^{\circ} \mathrm{C}\right)$ & 1080 \\
\hline Suhu Solid $\left({ }^{\circ} \mathrm{C}\right)$ & 1070 \\
\hline Rentang pemadatan $\left({ }^{\circ} \mathrm{C}\right)$ & 10 \\
\hline Kepadatan pada $20^{\circ} \mathrm{C}(\mathrm{kg} / \mathrm{dm} 3)$ & 8.9 \\
\hline $\begin{array}{l}\text { Koefisien ekspansi linear }\left(10-6 /{ }^{\circ}\right. \\
\text { C) }\end{array}$ & 18 \\
\hline $\begin{array}{l}\text { Kapasitas panas spesifik pada } 20^{\circ} \\
\text { C }(\mathrm{J} /(\mathrm{kg} . \mathrm{K}))\end{array}$ & 377 \\
\hline $\begin{array}{l}\text { Konduktivitas termal pada } 20^{\circ} \mathrm{C} \\
(\mathrm{W} /(\mathrm{mK}))\end{array}$ & 322 \\
\hline
\end{tabular}




\begin{tabular}{|l|c|}
\hline $\begin{array}{l}\text { Konduktivitas listrik pada } 20^{\circ} \mathrm{C} \\
(\% \text { IACS })\end{array}$ & 80 \\
\hline $\begin{array}{l}\text { Tahanan listrik pada } 20^{\circ} \mathrm{C}(10-8 \\
\Omega . m)\end{array}$ & 2.1 \\
\hline
\end{tabular}

\section{Parameter}

Secara konvensional menyatakan model aditif pengerasan yang bermain pada variabel jenis pengerasan plastisitas dan model multipliaktif pada tegangan viskositas. Sebuah pendekatan dimana dua mekanisme tersebut juga memungkinkan. Selain itu, tidak seperti kasus plastisitas, di sini kita dapat mempertimbangkan model di mana kekuatan bidang berkurang dari aslinya $(\sigma=0)$, dan tidak memiliki pengerasan [6]. Dengan demikian model yang paling umum adalah Norton (dengan dua parameter bahan $\mathrm{K}$ dan $\mathrm{n}$ ):

$$
\dot{\varepsilon}^{v p}=\left(\frac{|\sigma|-\sigma_{y}}{K}\right)^{n} \text { signe }(\sigma)
$$

Model penuaan untuk memperkenalkan variabel penuaan [9] yang diekspresikan oleh persamaan (model The blond-Devaux);

$$
\frac{d a}{d t}=\left[\frac{a \infty(T)-a}{\tau(T)}\right]
$$

$a \infty(T)=\%$ maksimum fase pelunakan

$\tau(T)=$ waktu tunggu proses

Dampak perubahan keadaan pengendapan pada perilaku mekanik material. Hal itu bervariasi antara dua nilai ekstrim yang sesuai;

- $\mathrm{a}=0$, materi tidak mengalami penuaan (pengobatan maksimal, baseline)

- $\mathrm{a}=1$, material memiliki usia penuh (pelunakan maksimum)

$$
K(a)=K_{v}+\left(K_{0}-K_{v}\right)(1-a)
$$

\section{METODA}

Pertama, studi ini difokuskan pada uji spescimen Isotermal dengan menggunakan mesin Gleeble di tahan pada temperatur konstan $750^{\circ} \mathrm{C}$ dan perhitungan numerik dilakukan untuk mengetahui evolusi mikrostruktur dalam elektroda dengan softwere SiDoLo.

$\begin{array}{ccc}\text { Hasil Uji } & \text { Gleeble } & \text { adalah simulator } \\ \text { Mesin } & \text { memungkinkan untuk }\end{array}$

menerapkan tegangan mekanik (tarik, kompresi) untuk menguji dngan pengontrolan suhu.

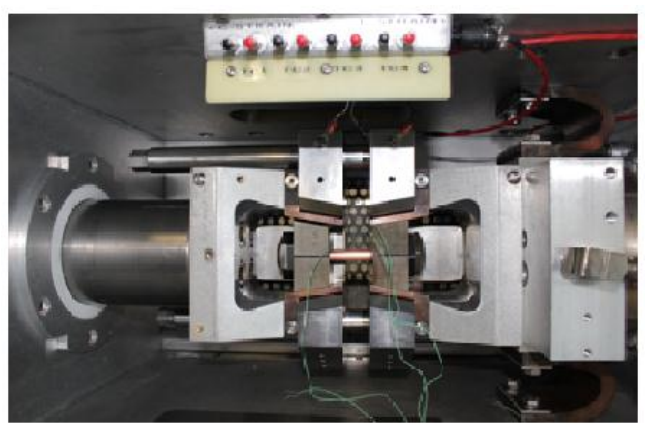

Gambar 2. Uji Isotermal dengan Mesin Gleeble

a. Specimen

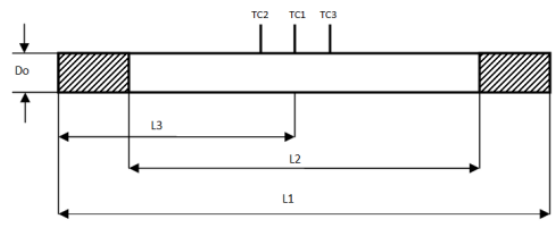

Gambar 3. Spesifikasi Specimen

\section{b. Hasil Isothermal}

Kurva hasil uji, menunjukkan parameter gaya dan temperature dengan waktu.

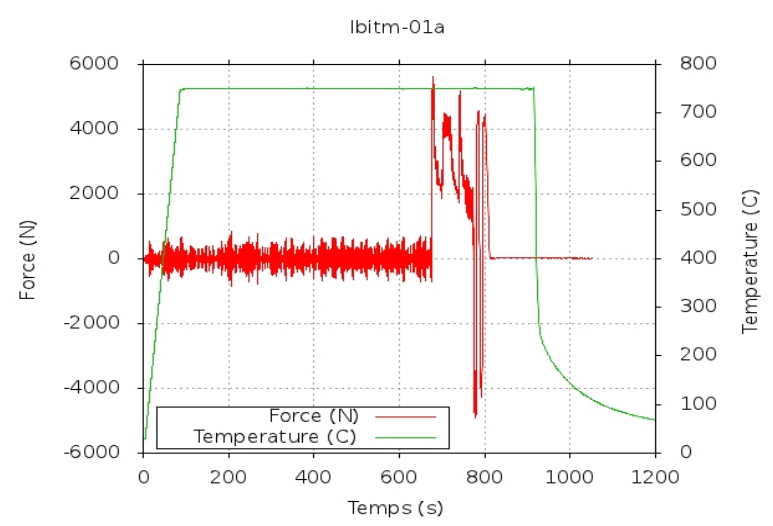

Gambar 4. Kurva perbandingan nilai gaya dan temperatur.

Specimen yang dipanaskan $750^{\circ} \mathrm{C}$ selama $600 \mathrm{~s}$ sebelum dilakukan pengujian mekanik.Sebuah suksesi tiga ketegangan-relaksasi dilakukan dalam tiga kecepatan deformasi yang berbeda untuk membatasi jumlah percobaan. Kemudian siklus ketegangan / kompresi ini dilakukan untuk mendapatkan informasi tentang pengerasan 


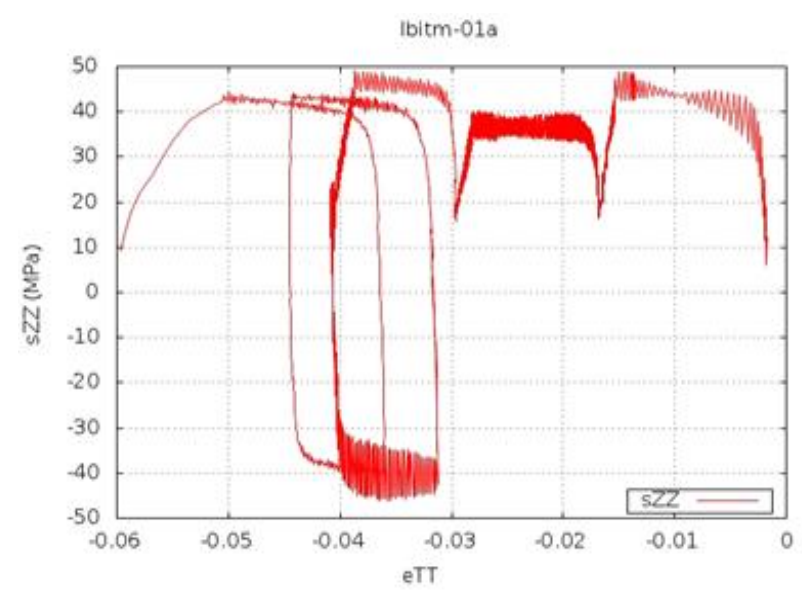

Gambar 5.Nilai constraintdan deformation selama beban tensile dan compression.

Dari Gambar diatas, dapat kita simpulkan bahwa material memiliki perilaku viskositas dan memiliki sedikit pengerasan.

\section{Numerical}

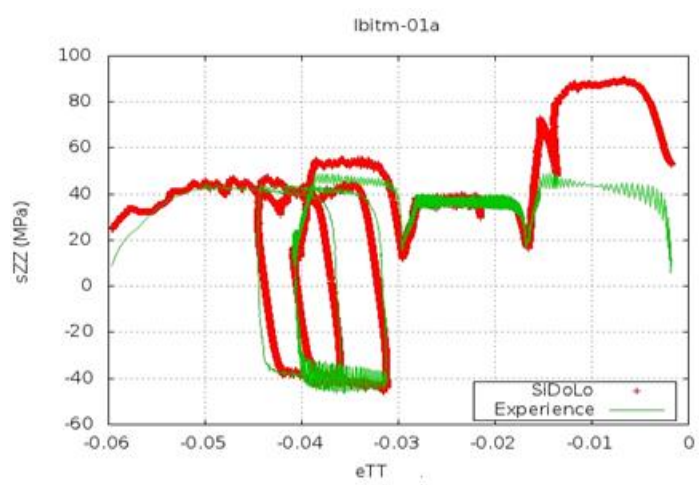

Gambar 9. Perbandingan deformasi dan tegangan

Pada Gambar 9 kita membandingkan kurva nilai tegangansebagai fungsi dari regangan, kurva merah menunjukkan hasil identifikasi SiDoLo, dan kurva hijau menunjukkan hasil experimental, tidak ada kurva yang sama pada traction pertama, ada jarak pada kurva (A).

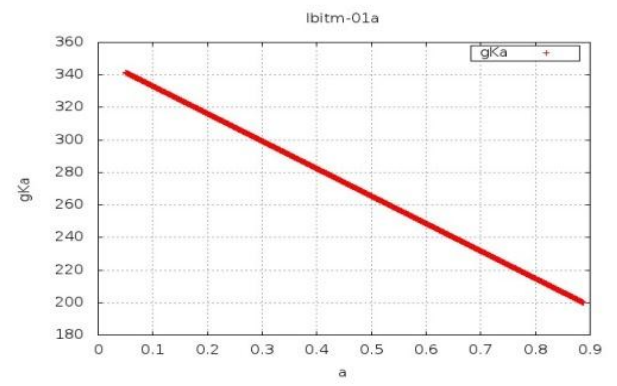

Gambar 10. Kurva hasil identifikasi SiDoLo

Kurva ini menunjukkan parameter penuaan.Hasil identifikasi dengan SiDoLo untuk mengetahui variabel penuaan. Hasil ini mengalami penuaan 0,9 .

\section{KESIMPULAN}

Studi ini dapat memberikan informasi perilaku $\mathrm{CuCr} 1 \mathrm{Zr}$ bahan dengan Pemodelan hukum elastis Visco Plastik dan Identifikasi variabel K (a) adalah parameter penuaan, realisasi pengujian isothermal dapat mencirikan penuaan elektroda $\mathrm{CuCr} 1 \mathrm{Zr}$ spot welding.

Kita bisa mengetahui nilai variabel penuaan spesimen adalah nilai antara 0-1, Hasil identifikasi penuaan material melalui perhitungan secara numerik menunjukkan hasil akhir 0.9 , maka kita dapat mengatakan spesimen yang telah diuji memiliki penuaan.

\section{TERIMA KASIH}

Prof.Philipe Pilvin dan Dr Elise Gauthier, mereka memberi saya banyak bimbingan dan pengajaran di LIMATB.

\section{REFERENSI/DAFTAR PUSTAKA}

[1] G. Sibilia, Modélisation du soudage par point - Influence des conditions interfaciales sur le procédé, Thèse de Doctorat, Polytechnique Nantes, 2003.

[2] R. Raoelison, Etude et modélisation des conditions interfaciales dans le procédés de soudage par points de tôles revêtues, Thèse de Doctorat, Université de Bretagne Sud, 2010.

[3] J.CLAEYS, T.DUPUY, P.VERRIER, Technique de l'ingénieur (soudage des tôles revêtues), BM 7 771[1-14], 2005.

[4] J.Wisniewski, Modélisation thermomécanique de la fissuration à chaud en soudage par faisceau d'électrons d'un alliage CuCrZr, Thèse de Doctorat, Université de Bretagne Sud, 2009.

[5] T.B. Massalski, J.L. Murray, L.H. Bennett, H. Baker. Binary Alloy Phase Diagrams American Society for Metals, Vol. 1, 1986.

[6] Elseiver, Influence of the manufacturing heat cycles on the CuCrZr properties, Journal of Nuclear Materials 307-311 (2002) 677-680. 
[7] G. Cailletaud, M. Tijani, Polycopy Mécanique Des Matériaux Solides, MINES Paris Tech, 2011. http://mms2.ensmp.fr/.

[8] J.Lemaitre, J.Louis Chaboche, A.Benallal, R.Desmorat, Mécanique des matériaux solides, Cours - Masters, écoles d'ingénieurs, Dunod, 2008.

[9] B BARLAS, Etude du comportement et de l'endommagement en fatigue d'alliages d'aluminium de fonderie. Thèse de doctorat, ENS Mines de Paris 2004.

[10] P. Pilvin. Notice d'utilisation de SiDoLo. Laboratoire Génie Mécanique et Matériaux Université de Bretagne-Sud. Version 2.4495. 2003

[11] Documentation ABAQUS version 6.8, www.simulia.com.

[12] Techniques de l'ingénieur [Cuivres alliés], V2 p11-p24, 2004. 